\title{
PENGARUH KAPITALISASI PASAR SAHAM DAN VARIABEL MAKROEKONOMI TERHADAP INDEKS HARGA SAHAM GABUNGAN DI BURSA EFEK INDONESIA
}

\author{
THE IMPACT OF STOCK MARKET CAPITALIZATION AND MACROECONOMIC VARIABLES ON \\ COMPOSITE INDEX IN INDONESIA STOCK EXCHANGE
}

\author{
Asep Kurnia Hidayat*), Muhammad Firdaus**), dan Bunasor Sanim*) \\ *) Sekolah Bisnis, Institut Pertanian Bogor \\ Jl. Raya Pajajaran, Bogor 16151 \\ ${ }^{* *}$ Departemen Ekonomi, Fakultas Ekonomi dan Manajemen, Institut Pertanian Bogor \\ Jl. Agatis Kampus IPB Darmaga, Bogor 16880
}

\begin{abstract}
This research aimed to analyze the impact of stock market capitalization and macroeconomic variables on Indonesia Composite Index (ICI) and formulate recommendations of strategies to enhance stock market capitalization. The analysis of macroeconomic data variables covered the inflation rate, oil price, gold price, and Hang Seng Index from 2008 to 2017. The model used in this research was Error Correction Model (ECM) and Analytical Hierarchy Process (AHP). The results showed that in general, all independent variables in the long run had a positively significant impact, except for inflation which had a negatively significant impact. In short run, stock market capitalization, inflation, world oil price, and HSI had a significant impact, while gold price had an insignificant impact. Stock market capitalization and HSI had a positive impact, while inflation and world oil price had a negative impact. Error Correction Term coefficient had an impact of -0.207329 with a negatively significant direction at the significance level of 5\%. It showed that the adjustment mechanism process in the long run equilibrium lasted for 5 quarters. Stock market capitalization and HSI had a positive impact, while inflation and world oil price had a negative impact. Stock market capitalization, both in short and long run, had a positively significant and more dominant impact than that of macroeconomic variables. In consequence, a strategy to enhance stock market capitalization in IDX is required. Based on the results of AHP vertical analysis, factors that become a priority in the strategy is the policy (monetary and capital markets). The recommended alternative strategy encourages the increase in large cap stock investments.
\end{abstract}

Keywords: capitalization, composit indexs, macroeconomic, ECM, AHP

\begin{abstract}
Abstrak: Penelitian ini bertujuan menganalisis pengaruh kapitalisasi pasar saham dan variabel makroekonomi terhadap IHSG dan kemudian merumuskan rekomendasi strategi meningkatkan kapitalisasi pasar saham. Data variabel makroekonomi yang dianalisis inflasi, harga minyak, harga emas dan indeks Hang Seng dari 2008 sampai 2017. Model penelitian menggunakan Error Correction Model (ECM) dan Analytical Hierarchy Process (AHP). Hasil penelitian menunjukan bahwa secara umum seluruh variabel independen dalam jangka panjang berpengaruh positif signifikan, hanya inflasi berpengaruh negatif signifikan. Pada jangka pendek, kapitalisasi pasar saham, inflasi, harga minya dunia dan HSI berepengaruh signifikan, Sedangkan harga emas tidak berpengaruh signifikan. Kapitalisasi pasar saham dan Indeks Hang Seng berpengaruh positif. Sedangkan inflasi dan harga minyak dunia berpengaruh negative. Koefisien Error Corection Term memiliki pengaruh sebesar - 0,207329 dengan arah negative signifikan pada taraf 5\%, menunjukan bahwa proses penyesuaian (Adjusment Mechanism Prosses) pada keseimbangan jangka panjang berlangsung selama 5 triwulan. Kapitalisasi pasar saham dalam jangka pendek dan panjang berpengaruh positif signifikan dan dominan daripada pengaruh variabel makroekonomi. Untuk itu diperlukan strategi meningkatkan kapitalisasi pasar saham. Berdasarkan hasil analisis vertikal AHP, faktor yang menjadi prioritas dalam strategi adalah kebijakan (pasar modal dan moneter). Alternatif strategi yang direkomendasikan mendorong peningkatan investasi saham-saham berkapitalisasi besar.
\end{abstract}

Kata kunci: kapitalisasi, IHSG, makroekonomi, ECM, AHP

\footnotetext{
${ }^{1}$ Alamat Korespondensi:

Email: asepkurniahidayat@yahoo.com
} 


\section{PENDAHULUAN}

Pasar modal mempunyai peranan penting dalam perekonomian nasional karena memberikan gambaran mengenai kondisi perekonomian negara. Pasar modal juga menjadi alternatif penghimpunan dana masyarakat selain sistem perbankan. Berdasarkan fungsinya pasar modal merupakan tempat bertemunya antara pembeli dan penjual ekuitas dengan resiko untung dan rugi (Handiani, 2014).

Tempat transaksi pasar modal di Indonesia adalah Bursa Efek Indonesia (BEI). BEI terbentuk hasil merger dari Bursa Efek Jakarta dan Bursa Efek Surabaya, tanggal 30 November 2007. Salah satu tujuan merger adalah untuk meningkatkan efesiensi pasar modal dan mendorong peningkatan daya tarik serta daya saing industri di tingkat internasional. Selain meningkatkan efesiensi, merger juga mendorong perubahan kapitalisasi pasar saham. Kapitalisasi merupakan sebuah indikator bursa yang diperoleh dari hasil perkalian jumlah saham dengan harga pasar saham. Perubahan kapitalisasi pasar dapat dipengaruhi oleh adanya perubahan harga dan penerbitan atau pengurangan saham di bursa (Mulyono, 2015). Pasca merger perkembangan kinerja BEI, seperti terlihat pada Tabel 1.

Berdasarkan Tabel 1, menunjukkan bahwa proyeksi kapitalisasi pasar saham tahun 2008 sebesar Rp1.076,49 triliun dan emiten sebanyak 396 perusahaan. Data tersebut terus berkembang sampai tahun 2017, kapitalisasi pasar sebesar Rp7.052,39 triliun dan emiten sebanyak 566. Perusahaan tercatat mengalami penambahan sebesar 170, dengan rata-rata penambahan per tahun sebesar 17 perusahaan.

Selain kapitalisasi yang digunakan sebagai indikator dalam mengukur kinerja bursa, juga digunakan indikator indeks. Indeks yang sering diperhatikan investor ketika berinvestasi di BEI adalah Indeks Harga Saham Gabungan (IHSG), sebagaimana terproyeksi pada Tabel 1. Perubahan kapitalisasi pasar saham mempunyai korelasi positif terhadap perubahan IHSG dan melalui IHSG seorang investor dapat melihat kondisi pasar apakah sedang naik atau turun. IHSG yang sedang naik menunjukan kondisi pasar yang sedang bergairah, begitu juga sebaliknya. Perbedaan kondisi ini memerlukan strategi dari investor dalam berinvestasi (Prasetyanto, 2016).

Terdapat banyak faktor yang memengaruhi naik dan turunnya IHSG selain dari kapitalisasi, terutama faktor ekonomi, baik yang bersifat mikro maupun makro. Faktor mikro ekonomi, terdiri dari laba per saham, dividen per saham, nilai buku per saham, debt to equity ratio, dan rasio keuangan lainnya. Faktor makro ada yang besifat ekonomi maupun nonekonomi. Faktor makro non-ekonomi mencakup peristiwa politik domestik, peristiwa sosial, peristiwa hukum dan peristiwa politik internasional. Faktor makroekonomi terdiri dari inflasi, tingkat bunga, kurs valuta asing, tingkat pertumbuhan ekonomi, harga bahan bakar minyak dunia, harga emas dunia dan indeks saham regional. Indeks regional yang paling berpengaruh adalah Indeks Dow Jones, Indeks Nikkei 225 dan Indeks Hang Seng (Halim, 2011).

Tabel 1. Proyeksi emiten, kapitalisasi pasar dan indeks harga saham gabungan di Bursa Efek Indonesia periode Desember 2008 - Desember 2017

\begin{tabular}{cccccc}
\hline Tahun & $\begin{array}{c}\text { Perusahaan } \\
\text { Tercatat }\end{array}$ & $\begin{array}{c}\text { Emiten } \\
\text { Listing* }\end{array}$ & $\begin{array}{c}\text { Perusahaan } \\
\text { Delisted }\end{array}$ & $\begin{array}{c}\text { Kapitalisasi } \\
\text { Pasar (Triliun) }\end{array}$ & IHSG \\
\hline 2008 & 396 & 17 & 6 & $1.076,49$ & $1.355,41$ \\
2009 & 398 & 12 & 12 & $2.019,38$ & $2.534,36$ \\
2010 & 420 & 24 & 1 & $3.247,10$ & $3.703,51$ \\
2011 & 440 & 25 & 5 & $3.537,29$ & $3.821,99$ \\
2012 & 462 & 24 & 4 & $4.126,99$ & $4.316,69$ \\
2013 & 483 & 30 & 7 & $4.219,02$ & $4.274,18$ \\
2014 & 506 & 20 & 1 & $5.228,04$ & $5.226,95$ \\
2015 & 521 & 16 & 3 & $4.872,70$ & $4.593,01$ \\
2016 & 537 & 14 & 2 & $5.753,61$ & $5.296,71$ \\
2017 & 566 & 37 & 8 & $7.052,39$ & $6.355,65$ \\
\hline
\end{tabular}

Sumber: Diolah dari data mingguan Statistika Pasar Modal Indonesia, OJK pada minggu II April 2014- minggu IV, Januari 2018. *) Tidak termasuk saham preferen dan saham seri B. 
Pengaruh faktor makroekonomi tidak selalu sama terhadap harga saham. Misalnya, kenaikan nilai kurs dolar AS terhadap rupiah berdampak positif terhadap harga saham emiten dibidang ekspor, tetapi berdampak negatif terhadap harga saham emiten yang memiliki utang valuta asing. Faktor makroekonomi tidak memengaruhi kinerja perusahaan secara seketika, melainkan pelahan. Sebaliknya, harga saham akan terpengaruh seketika oleh perubahan makroekonomi, karena para investor lebih cepat bereaksi.

Ketika perubahan makroekonomi terjadi, para investor akan memperhitungkan dampaknya terhadap kinerja perusahaan, kemudian mengambil keputusan. Hal ini membuat harga saham lebih cepat menyesuaikan diri terhadap perubahan makroekonomi daripada kinerja perusahaan yang bersangkutan (Astuti et al. 2016). Berdasarkan uraian diatas, pengaruh kapitalisasi pasar saham dan variabel makroekonomi terhadap IHSG di BEI menurut pengamatan penulis menarik untuk diteliti.

Peneliti terdahulu telah bayak dilakukan terhadap masalah yang sama, dengan prediktor yang berbeda beda, baik sebagian maupun beberapa bagian dari variabel makroekonomi yang digunakan. Seperti penelitian Subeniotis et al. (2011). Yang berjudul How inflation, market capitalization, Idustrial Production and Economic Sentiment Indicator Affect in UE-12 Stock Market. Alat analisis yang digunakan regresi berganda dengan data panel dari 2000 sampai 2005. Hasil penelitian menyimpulkan kapitalisasi pasar, produk industri dan indikator ekonomi berpengaruh positif signifikan sedangkan inflasi tidak berpengaruh terhadap pasar saham di UE-12. Witjaksono (2010), juga melakukan penelitian di Indonesia dengan menggunakan model analisis regresi berganda. Tujuan penelitian untuk mengetahui pengaruh tingkat suku bunga SBI, harga minyak dunia, kurs Rupiah, Indeks Nikkei dan Indeks Dow Jones terhadap IHSG. Hasil penelitian menyimpulkan tingkat suku bunga SBI dan Kurs Rupiah berpengaruh negatif terhadap IHSG. Sementara harga minyak dunia, harga emas dunia, Nikkei dan Indeks Dow Jones berpengaruh positif terhadap IHSG.

Sulistya (2008), menggunakan metode analisis VECM untuk meneliti pengaruh variabel-variabel makroekonomi dan beberapa indeks dunia terhadap IHSG. Hasi penelitian menunjukkan bahwa dalam jangka pendek inflasi, SBI, Indeks S\&P 500, dan Nikkei memberikan pengaruh positif. FTSE 100 dan STI 30 memberikan pengaruh negatif terhadap harga saham. Dalam jangka panjang inflasi, SBI dan indeks S\&P 500, Nikkei dan STI 30 memberikan pengaruh negatif. Sementara itu pada FTSE 100 memberikan pengaruh positif terhadap harga saham.

Handiani (2014), meneliti pengaruh harga emas dunia, harga minyak dunia dan nilai tukar Dolar Amerika Serikat/Rupiah terhadap IHSG pada periode 2008 sampai 2013. Metode analisis yang digunakan adalah model analisis regresi berganda. Hasil penelitian menyimpulkan bahwa dalam jangka pendek inflasi, SBI, Indeks S\&P 500, Nikkei memberikan pengaruh positif. Sedangkan FTSE 100 dan STI 30 memberikan pengaruh negatif terhadap harga saham. Penelitian ini didukung oleh Rahman et al. (2017) yang menganalisis dampak dari variabel makroekonomi yang dipilih pada indeks S\&P, BSE, SME, IPO. Metode analisis yang digunakan adalah analisis korelasi, multiple regression dan tes granger kausalitas. Hasil penelitian menyimpulkan bahwa tingkat bunga memiliki dampak positif yang signifikan pada Indeks IPO UKM. Sedangkan, nilai tukar memiliki dampak negatif. Temuan lain juga menunjukkan tingkat Inflasi dan Tingkat Bunga memiliki dampak positif yang signifikan pada indeks IPO UKM.

Penelitian tentang strategi peningkatan kapitalisasi pasar saham dilakukan oleh Bettman et al. (2011) di Australian Stock Exchange dengan metode Analytical Hierarchy Process (AHP). Hasil penelitian menunjukkan bahwa strategi prioritas untuk meningkatkan kapitalisasi pasar saham adalah investasi pasar saham berkapitalisasi rendah dengan intensitas yang tinggi. Penelitian yang senada, juga dilakukan oleh Odior dan Nwaogwugwu (2016). Hasil penelitiannya menyatakan bahwa dalam strategi meningkatkan kapitalisasi pasar saham, faktor yang menjadi prioritas adalah meningkatkan kebijakan moneter yaitu suku bunga bank, treasury bills, kontrol kredit langsung (direct credit control) dan jumlah uang beredar.

Persamaan dengan penelitian yang dilakukan penulis adalah dependen variabel yang digunakan IHSG dan independen variabelnya menggunakan makroekonomi. Perbedaannya, penelitian terdahulu hanya variabel makroekonomi saja yang dijadikan variabel independen. Sedangkan penelitian yang dilakukan penulis ada penambahan variabel kapitalisasi pasar saham. Alat analisis yang digunakan pada penelitian terdahulu 
regresi berganda, VECM dan GARCH-M. Penulis menggunakan Error Corection Model (ECM) dan data yang digunakan selama 10 tahun dari Januari 2008 sampai Desember 2017. Sedangkan peneliti terdahulu data yang digunakannya kurang dari 10 tahun. Sealain itu penelitian penulis merekomendasikan strategi meningkatkan kapitalisasi, dengan menggunakan medel AHP, sedangkan peneliti terdahulu tidak merekomendasikan strategi. Perbedaan penelitian mengenai rekomendasi strategi dengan penelitian Bettman et al. (2011), Odior dan Nwaogwugwu (2016) adalah tempat penelitian dan waktu penelitian yang berbeda. Serta hasil penelitian yang terpokus pada rekomendasi strategi, sedangkan untuk masalah makro ekonomi terhadap harga saham tidak dianalisis.

Alasan yang menarik penulis melakukan penelitian ini selain konsef teori diatas juga dikarenakan pasca merger perkembangan kinerja BEI semakin baik, ditandai makin banyaknya perusahaan listed, semakin tingginya peningkatan kapitalisasi pasar dan IHSG. Bahkan menurut Nicky Hogan Direktur Pengembangan BEI, kenaikan IHSG dalam 10 tahun terakhir merupakan yang tertinggi di antara bursa-bursa di seluruh dunia. Kenaikanya sebesar $227,60 \%$. Tidak ada negara lain yang lebih tinggi dari itu, di tengah penjualan investor asing lebih dari Rp20 triliun, indeks saham Indonesia tetap mengalami kenaikan $13,87 \%$. Begitu juga investor baru yang terus bertambah dan berkontribusi sebesar $54,2 \%$ terhadap kenaikan transaksi saham harian sepanjang tahun 2017. Dimana kenaikan transaksi tersebut, sebesar 22,6\% diantaranya merupakan kontribusi para investor individu Indonesia (Djumena, 2017).

Semakin bertambahnya investor baru dan, agar tidak terjadi over dimand atas investasi disektor equitas maka harus ada strategi meningkatkan kapitalisasi pasar melalui peningkatan emiten listing. Sehingga supply dan dimand equitas berjalan seimbang. Di samping itu arus informasi dan efesiensi pasar modal juga harus terus ditingkatkan sebagai penunjang kelancaran transaksi, sehingga diharapkan dapat mendorong peningkatan daya tarik dan daya saing industri di tingkat internasional (Aditya et al. 2018).

Selain peningkatan kapitalisasi pasar saham dan peningkatan investor baru sebagaimana yang diuraikan di atas, faktor makro ekonomi juga memengaruhi perkembangan IHSG pasca merger. Seperti, tingkat inflasi yang semakin rendah, turunnya harga minyak dunia dan krisis ekonomi global juga menghantam IHSG. Selama 10 tahun krisis ekonomi global terjadi pada tahun 2008, dipicu oleh krisis subfrim morthage di Amerika Serikat. Kemudian krisis tahun 2013, dipicu oleh meningkatnya kekhawatiran terhadap kebijakan stimulus dari The Fed yang berdampak pada penurunan kinerja pasar modal regional. Krisis selanjutnya tahun 2015, dipicu oleh turunya kepercayaan pelaku pasar modal, yaitu spekulasi atas kenaikan suku bunga acuan Bank Sentral Amerika Serikat dan tekanan pelambatan ekonomi China (Amran, 2015). Seluruh faktor makro ekonomi tersebut sangat berperan terhadap pergerakan IHSG.

Tujuan penelitian ini adalah menganalisis pengaruh kapitalisasi pasar saham dan variabel makroekonomi terhadap IHSG di BEI. Kemudian merumuskan rekomendasi strategi meningkatkan kapitalisasi pasar saham di BEI.Variabel yang diteliti terdiri atas kapitalisasi pasar saham, inflasi, harga minyak dunia, harga emas dunia dan Indeks Hang Seng dari Januari 2008 sampai Desember 2017. Proxy pemilihan Indek Hang Seng atas pertimbangan indeks ini sama dengan IHSG, yaitu berdasarkan nilai, perhitungannya menggunakan seluruh populasi dan secara geografis lebih dekat dengan perbedaan waktu yang paling sedikit dibandingkan indeks Dow Jones dan Nikkei 225 (Frensidy, 2006). Seluruh variabel yang diteliti merupakan variabel terpilih secara statistik dan ekonometrik serta merupakan representasi dari seluruh variabel makroekonomi yang telah diuraikan.

\section{METODE PENELITIAN}

Data yang digunakan dalam penelitian ini adalah data primer dan sekunder. Data primer diperoleh melalui wawancara dan kuesioner dengan empat pakar dari BEI dan dua pakar dari BI. Sedangkan data sekunder diperoleh dari internet berupa data time series bulanan dari Januari 2008 sampai Desember 2017, kemudian diolah menjadi data triwulanan dengan menggunakan metode rata rata. Data yang diolah terdiri dari IHSG dan kapitalisasi pasar saham bersumber dari OJK. Data inflasi dari BI, harga minyak dunia dari West Texas Intermediate (WTI), harga emas dunia dari London Gold Fiking Ltd., dan Indeks Hang Seng dari yahoo finance. Spesifikasi variabel yang digunakan, sebagaimana terlihat pada Tabel 2 . 
Tabel 2. Spesifikasi variabel

\begin{tabular}{ll}
\hline Variabel & Definisi \\
\hline IHSG & Indeks Harga Saham gabungan. Indeks yang sering digunakan investor ketika berinvestasi di BEI \\
Kapitalisasi & Merupakan perkalian jumlah saham dengan harga pasar saham secara keseluruhan, kenaikan kapitalisasi \\
pasar saham & pasar saham dipengaruhi oleh kenaikan harag, bertambah emiten listed dan merger \\
Inflasi & Inflasi menggambarkan kenaikan harga barang dan jasa yang dikonsumsi masyarakat \\
$\begin{array}{l}\text { Harga minyak } \\
\text { dunia }\end{array}$ & $\begin{array}{l}\text { Harga minyak dunia adalah harga spot minyak dunia WTI yang terbentuk akibat akumulasi } \\
\text { Harga emas } \\
\text { dunia }\end{array}$ \\
HSI & Harga emas London Gold Fiking Ltd yang terbentuk akibat akumulasi supply dan demand \\
& Hang Seng Index (HSI), merupakan refpleksi performance dari nilai kapitalisasi seluruh nilai saham \\
& yang di perdagangkan The Stock Exchange of Hong Kong Ltd \\
\hline
\end{tabular}

Data time series yang digunakan dalam penelitian ini mensyaratkan pengujian stasioner untuk menghindari spurious regression atau regresi palsu. Pengujian menggunakan uji formal Augmented Dickey-Fuller (ADF-test). Cara pengujian dengan membandingkan nilai uji ADF-test statistik dengan nilai kritis Mac. Kinnon. Jika nilai ADF-test statistik $>$ nilai kritis Mac. Kinnon $10 \%$ atau nilai probabilitas $>0,01$ maka dapat dikatakan data tidak stasioner. Tahap selanjutnya mentranformasi data tidak stasioner menjadi stasioner menggunakan ADF-test statistic dengan unit root test pada first difference. Nilai ADF-tes statistik yang dihasilkan dibandingkan dengan nilai kritis Mac. Kinnon. Jika nilai ADF-test statistic < nilai kritis 10\% atau nilai probabilitas $<0,01$ maka data dikatakan bersifat stasioner.

Hasil uji stasioner yang menyatakan seluruh data non stasioner pada level dan stasioner pada first different. Selanjutnya dilakukan uji kointegrasi. Pengujian dilakukan dengan membandingkan nilai ADF-test statistik dengan nilai kritis Mac. Kinnon. Jika nilai ADFtest statistik < nilai kritis $10 \%$ atau nilai probabilitas < 0,01 menunjukan residual persamaan regresi stasioner pada level dan mengindikasikan terdapat hubungan kointegrasi diantara variabel yang digunakan, selanjutnya digunakan pengestimasian Engle-Granger Cointegrasion yang dikenal dengan ECM.

Model ECM merupakan model untuk mengkoreksi persamaan regresi diantara variabel yang secara individual tidak stasioner agar kembali ke nilai equilibriumnya di jangka panjang dengan syarat terdapatnya hubungan kointegrasi. Model untuk mengoreksi dinamakan model jangka pendek, dan nilai equilibrium di jangka panjang dinamakan model jangka panjang. Model ini diperkenalkan oleh Denis Sargan, dikembangkan oleh Hendry dan dipupulerkan oleh Engle dan Granger (Firdaus, 2012).

Setelah estimasi kemudian dicari variabel independen yang berpengaruh dominan terhadap variabel dependen. Variabel tersebut direkomendasikan untuk ditingkatkan dengan menggunakan model analisis AHP. Model AHP merupakan model yang memberikan kesempatan bagi perorangan atau kelompok untuk membangun gagasan dan mendefinisikan persoalan dengan asumsi mereka masing-masing (Natapura, 2009). Analisis AHP dikembangkan oleh Dr. Thomas L. Saaty dari Wharton School of Business pada tahun 1970-an (Marimin dan Magfiroh, 2013). Rumusan model ECM dan AHP yang digunakan pada penelitian ini sebagai berikut:

\section{Model ECM}

Model ECM dapat dirumuskan jika dua atau lebih variabel waktu adalah tidak stasioner namun saling berkointegrasi. Artinya, terdapat hubungan keseimbangan jangka panjang dari kedua variabel tersebut. Namun dalam jangka pendek terdapat kemungkinan terjadi disequilibrium dan untuk mengatasinya digunakan koreksi dengan model ECM. Model ECM yang digunakan dalam penelitian ini menggunakan model log, Model ini memiliki keunggulan pada koefisien slop $\beta 2$. Sebab nilai koefisien slop tersebut sesungguhnya merupakan ukuran elastisitas. Koefisien slop merupakan tingkat perubahan pada variabel dependen dalam persen bila terjadi perubahan pada variabel independen dalam persen (Nachrowi dan Usman, 2006). Persamaan jangka panjangnya dinyatakan sebagai berikut: 


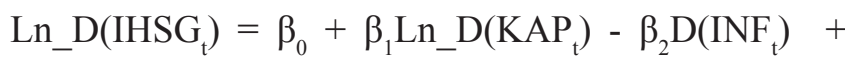
$\beta_{3} \operatorname{Ln}_{-} \mathrm{D}\left(\mathrm{MNYK}_{\mathrm{t}}\right)+\beta_{4} \mathrm{Ln}_{-} \mathrm{D}\left(\mathrm{EMAS}_{\mathrm{t}}\right)+$ $\beta_{5} \mathrm{Ln}_{-} \mathrm{D}\left(\mathrm{HSNG}_{\mathrm{t}}\right)+\varepsilon_{\mathrm{t}}$

Model tersebut memiliki sifat non stasioner sehingga akan mengakibatkan regresi lancung (spurious regresion) karena maknanya kurang memiliki arti. Selanjutnya, model tersebut dibentuk menjadi model yang dinamis dengan menyertakan kelambanan atau yang disebut model koreksi kesalahan. Model koreksi kesalahan Engle-Granger ditulis sebagai berikut:

Ln_D $\left(\mathrm{IHSG}_{\mathrm{t}}\right)=\beta_{0}+\beta_{1} \mathrm{Ln}_{-} \mathrm{D}\left(\mathrm{KAP}_{\mathrm{t}}\right)-\beta_{2} \mathrm{D}\left(\mathrm{INF}_{\mathrm{t}}\right)+$ $\beta_{3} \mathrm{Ln}_{-} \mathrm{D}\left(\mathrm{MNYK}_{\mathrm{t}}\right)+\beta_{4} \mathrm{Ln}_{-} \mathrm{D}\left(\mathrm{EMAS}_{\mathrm{t}}\right)+$ $\beta_{5} \mathrm{Ln}_{-} \mathrm{D}\left(\mathrm{HSNG}_{\mathrm{t}}\right)-\gamma \mathrm{ECT} \mathrm{t}_{\mathrm{t}-1}+\varepsilon_{\mathrm{t}}$

Keterangan: $\beta 0$ (Konstanta); $\beta \mathrm{i}$ (Koefisien regresi i); ECT (Ln_D(IHSG $)-\beta_{0}-\beta_{1}$ Ln_D(KAP $)-$ $\beta_{2} \mathrm{D}\left(\mathrm{INF}_{\mathrm{t}}\right)-\beta_{3} \mathrm{Ln}_{-} \mathrm{D}\left(\mathrm{MNYK}_{\mathrm{t}}\right)-\beta_{4} \mathrm{Ln} \_\mathrm{D}\left(\mathrm{EMAS}_{\mathrm{t}}\right)$ - $\beta_{6} \mathrm{Ln}_{-} \mathrm{D}\left(\mathrm{HSNG}_{\mathrm{t}}\right)$ ); $\mathrm{ECT}_{\mathrm{t}-1}$ (error correction term). Model ECM memiliki karakteristik dimasukannya Error Correction Term (ECT) dalam persamaan.

Model ini valid jika koefisien ECT signifikan secara statistik pada probabilitas kurang dari $5 \%$.

\section{Uji Statistik}

Langkah selanjutnya adalah melakukan uji analisis apakah variabel variabel independen mempunyai pengaruh yang signifikan terhadap variabel dependen. Analisis uji signifikansi ini menggunakan uji parsial dan uji simultan.

\section{Uji secara parsial}

Ada dua kemungkinan mengenai signifikansi sebuah koefisien regresi yaitu sama dengan nol dan tidak sama dengan nol. Pengujian dilakukan untuk mengetahui secara parsial variabel variabel bebas yang berpengaruh signifikan terhadap variabel terikat. Pengujian dilakukan mengunakan uji satu sisi, dengan hipotesis sebagai berikut:

Ho : $\beta i=0$, artinya tidak ada pengaruh positif atau negatif signifikan dari variabel independe terhadap variabel dependen.

$\mathrm{Ha}: \beta \mathbf{i}<0$ atau $\beta \mathrm{i}>0$. Ada pengaruh negatif atau positif signifikan dari variabel independen terhadap variabel dependent.
Adapun kriteria pengujiannya adalah Jika nilai $t_{\text {hitung }}$ $>\mathrm{t}_{\text {tabel }}$ atau probabilitas $\mathrm{T}_{\text {test }} \alpha<0,05$ maka Ho ditolak atau menerima $\mathrm{Ha}$, artinya variabel bebas tersebut berpengaruh negatif atau positif secara signifikan terhadap variabel terikat; Jika nilai thitung $<$ ttabel atau probabilitas $\mathrm{t}_{\text {test }} \alpha>0,05$ maka Ho diterima atau menolak $\mathrm{Ha}$, artinya variabel bebas tersebut tidak berpengaruh negatif atau positif secara signifikan terhadap variabel dependen.

Uji secara simultan (Uji F)

Untuk mengetahui secara simultan variabel independen berpengaruh signifikan atau tidak terhadap variabel dependen, maka dilakukan pengujian dua sisi dengan hipotesis sebagai berikut:

H0 : $\beta 0=0$, artinya tidak ada pengaruh signifikan dari variabel independen

Ha : setidaknya salah satu $\beta i \neq 0$, terdapat pengaruh signifikan dari variabel independen terhadap variabel dependen.

Kriteria pengujiannya adalah Jika nilai $\mathrm{F}_{\text {hitung }}>$ Ftabel atau probabilitas $\mathrm{F}_{\text {tabel }} \alpha<0,05$ maka Ho ditolak atau menerima $\mathrm{Ha}$, artinya variabel independen secara bersama sama berpengaruh signifikan terhadap variabel dependen; Jika $\mathrm{F}_{\text {hitung }}<\mathrm{F}_{\text {tabel }}$ atau probabilitas $\mathrm{F}_{\text {tabel }} \alpha$ 0,05 maka Ho diterima dan Ha ditolak, artinya variabel independen secara bersama sama tidak berpengaruh signifikan terhadap variabel dependen.

\section{Analytical HierarchyProcess (AHP)}

Analytical Hierarchy Process (AHP) adalah metode pengambilan keputusan dengan melakukan perbandingan berpasangan antara kriteria pilihan dan juga perbandingan berpasangan antara pilihan yang ada (Ma'arif dan Tanjung, 2003). Beberapa hal penting yang perlu diperhatikan dalam metode AHP sebagai berikut: 1) Matriks Individu (matriks yang berisikan penilaian pendapat individu yang berasal dari hasil komparasi berpasangan suatu elemen terhadap elemen lainnya);2) Matriks Gabungan (susunan matrik baru yang elemenelemennya berasal dari rata-rata geometrik elemen matrik pendapat individu yang rasio konsistensinya (CR) dibawah 10\%); 3) Penentuan prioritas elemen dan pengujian konsistensi (Terdapat beberapa rumus yang digunakan untuk menentukan prioritas elemen-elemen keputusan pada setiap tingkat hirarki dan tingkat konsistensi. Rumus-rumus tersebut adalah sebagai berikut: CI $($ Indeks Konsistensi $)=(\lambda$ maks $-n) /(n-1)$ 
dan CR $($ Rasio Konsistensi $)=(\mathrm{CI} / \mathrm{RI})$. Random indeks dari matrik berorde 1-15 dengan sampel berukuran 100 dapat dilihat pada Tabel 3); 4) Revisi pendapat (Apabila rasio konsistensi (CR) diatas 10\% maka matriks perlu direvisi. Untuk menentukan elemen yang harus direvisi, hitung selisih absolut seluruh elemen matriks dengan perbandingan bobotnya); 5)Penentuan prioritas terhadap sasaran utama (Penentuan prioritas setiap elemen terhadap sasaran utama dilakukan pengolahan vertikal antar elemen).

Kerangka pemikiran penelitian diawali dengan penentuan indikator kinerja BEI, yaitu IHSG. Perkembangan IHSG dipengaruhi faktor ekonomi, baik mikro maupun makro. Faktor mikro yang dianalisis adalah kapitalisasi pasar saham. Sedangkan, laba persaham, dividen persaham, debt to equity ratio dan ratio keuangan lainnya tidak dianalisis. Faktor makro terdiri dari faktor makroekonomi dan faktor makro non ekonomi. Faktor makro non ekonomi seperti politik domestik, peristiwa sosial, peristiwa hukum dan politik internasional juga tidak dianalisis. Faktoryang dianalisis adalah faktor makro ekonomi seperti inflasi, harga minyak dunia, harga emas dunia dan indeks regional. Indek regional yang dipilih adalah Indeks Hang Seng. Seluruh variabel terpilih merupakan variabel terbaik secara statistik dan ekonometrik. Variabel terpilih dari faktor mikro dan makro ekonomi digabungkan untuk dianalisis dalam model ECM. Setelah diperoleh hasil analisis, kemudian dirumuskan rekomendasi strategi dengan menggunakan metode AHP dan kemudian dirumuskan implikasi managerial. Kerangka pemikiran penelitian selengkapnya pada Gambar 2.

Tabel 3. Random indeks matriks

\begin{tabular}{cccccc}
\hline $\mathrm{n}$ & $\mathrm{RI}$ & $\mathrm{N}$ & $\mathrm{RI}$ & $\mathrm{N}$ & $\mathrm{RI}$ \\
\hline 1 & 0,00 & 6 & 1,24 & 11 & 1,51 \\
2 & 0,00 & 7 & 1,32 & 12 & 1,48 \\
3 & 0,58 & 8 & 1,41 & 13 & 1,56 \\
4 & 0,90 & 9 & 1,45 & 14 & 1,57 \\
5 & 1,12 & 10 & 1,49 & 15 & 1,49 \\
\hline
\end{tabular}

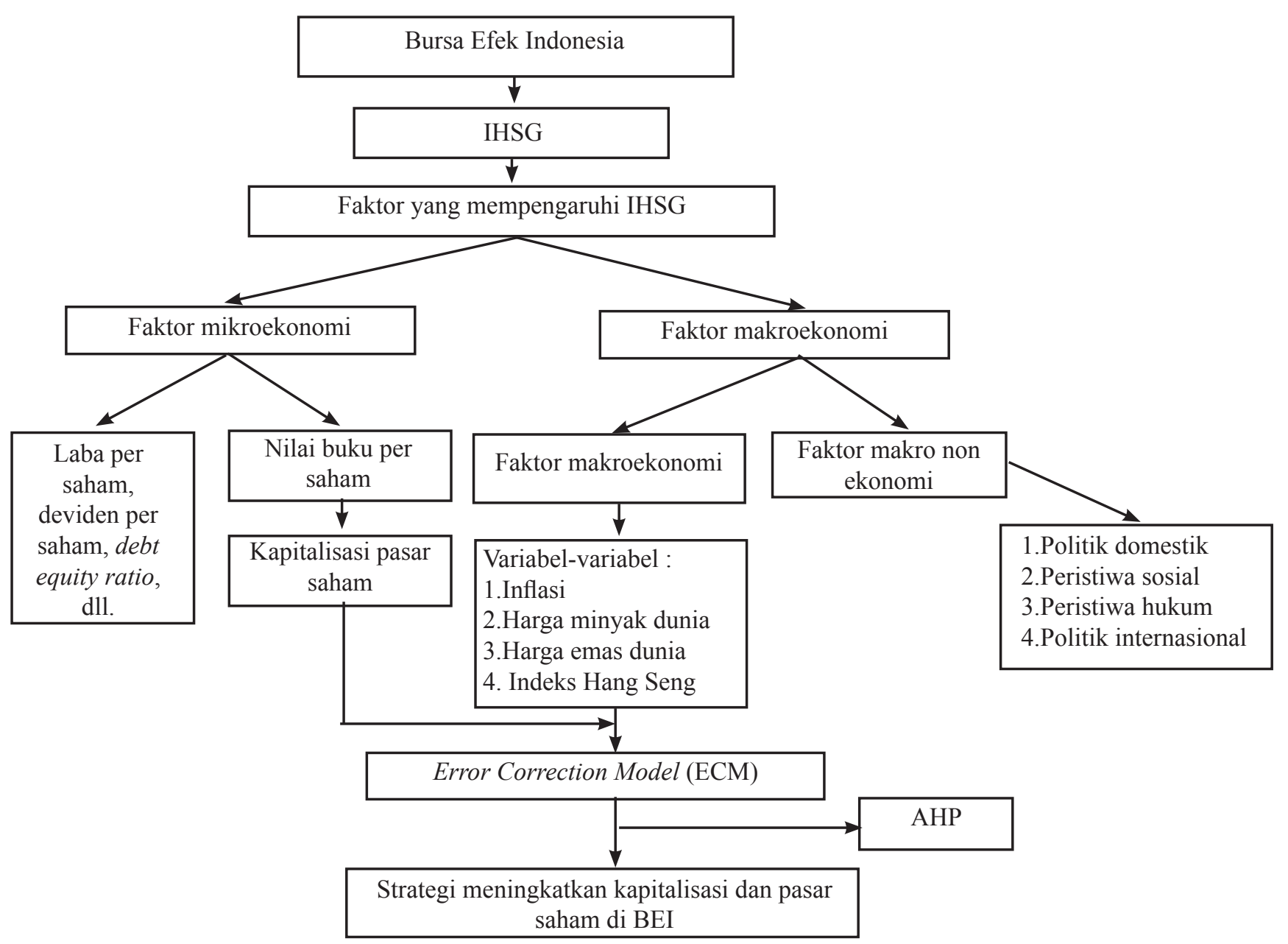

Gambar 1. Kerangka pemikiran penelitian 
Hipotesis yang diajukan dari kerangka pemikiran penelitian tersebut adalah sebagai berikut:

H1,0 : Kapitalisasi pasar saham, inflasi, suku bunga SBI, harga minyak dunia, harga emas dunia dan Indeks Hang Seng secara bersama sama tidak berpengaruh signifikan terhadap IHSG.

H1,a : Kapitalisasi pasar saham, inflasi, suku bunga SBI, harga minyak dunia, harga emas dunia dan Indeks Hang Seng secara bersama sama berpengaruh signifikan terhadap IHSG.

H2,0 : Kapitalisasi pasar saham tidak berpengaruh dan tidak signifikan terhadap IHSG.

$\mathrm{H}$,a : Kapitalisasi pasar saham berpengaruh dan signifikan terhadap IHSG.

$\mathrm{H} 3,0$ : Inflasi tidak berpengaruh dan tidak signifikan terhadap IHSG.

$\mathrm{H} 3$, a : Inflasi berpengaruh dan signifikan terhadap IHSG.

H4.0 : Harga miyak dunia tidak berpengaruh dan tidak signifikan terhadap IHSG.

$\mathrm{H} 4$,a : Harga miyak dunia berpengaruh dan signifikan terhadap IHSG.

H5.0 : Harga emas dunia tidak berpengaruh dan tidak signifikan terhadap IHSG.

$\mathrm{H} 5$,a : Harga emas dunia berpengaruh dan signifikan terhadap IHSG.

H6,0 : Indeks Hang Seng tidak berpengaruh dan tidak signifikan terhadap IHSG.

H6,a : Indeks Hang Seng berpengaruh dan signifikan terhadap IHSG.

\section{HASIL}

Pada proses estimasi data, data yang digunakan dalam penelitian ini menggunakan data time series yang mensyaratkan pengujian stasioner. Bila data tidak stasioner, tahap selanjutnya mentranformasi data tidak stasioner menjadi stasioner dengan unit root test pada first difference. Kemudian dilakukan uji kointegrasi. residual persamaan regresi stasioner pada level. Jika terdapat hubungan kointegrasi diantara variabel yang digunakan, selanjutnya pengestimasian Engle-Granger Cointegrasion. Estimasi dilakukan secara terstruktur dua tahap jangka penjang dan jangka pendek.

\section{Hasil Uji Stasioner}

Hasil uji stasioner menunjukkan data yang digunakan tidak stasioner pada level. Hal ini dapat dilihat dengan membandingkan nilai uji ADF test-statistik yang dihasilkan terhadap nilai kritis Mac. Kinnom untuk taraf nyata sebesar $10 \%$. Jika nilai ADF test-statistik lebih besar dari nilai kritis $10 \%$ atau nilai probabilitas lebih besar dari 0.01 maka data tidak stasioner, seperti terlihat pada Tabel 4. Tahap selanjutannya melakukan transformasi data tidak stasioner menjadi data stasioner dengan menggunakan uji ADF dengan unit root test pada first difference seperti pada Tabel 5. Dari Tabel 5 menunjukkan seluruh variabel telah stasioner pada first difference dengan taraf nyata $1 \%$ dan $5 \%$.

\section{Hasil Uji Kointegrasi}

Hasil uji stasioner yang menyatakan bahwa seluruh variabel bersifat non stasioner pada level dan stasioner pada first different. Langkah selanjutnya dilakukan pengujian untuk menemukan hubungan kointegrasi variabel persamaan regresi. Dari hasil uji kointegrasi nilai ADF test-statistic sebesar -4.673041. kemudian nilai ini dibandingkan dengan nilai kritis Mac Kinnon pada taraf nyata $1 \%$ sebesar -2.625606 . Hasil perbandingan menyatakan nilai ADF test-statistic $<$ nilai kriris Mac Kinnon atau dapat dilihat dari nilai Prob. $0,000<1 \%$, menunjukkan bahwa residual persamaan regresi stasioner pada tingkat level. Hal ini mengindikasikan terdapat hubungan kointegrasi diantara variabel yang digunakan sehingga selanjutnya dapat dilakukan pengestimasian Engle-Granger Cointegration.

\section{Estimasi Faktor-faktor yang Memengaruhi IHSG Dalam Jangka Panjang}

Hasil estimasi jangka panjang dari model ECM yang menganalisis pengaruh kapitalisasi pasar saham dan variabel makroekonomi yang terdiri dari kapitalisasi pasar saham, inflasi, harga minyak dunia, harga emas dunia dan Indeks Hang Seng terhadap IIHSG di BEI dapat dilihat pada Tabel 6 . 
Tabel 4. Tabel uji stasioner pada level atas variabel penelitian

\begin{tabular}{|c|c|c|c|c|c|c|}
\hline \multirow{2}{*}{ Variabel } & \multirow{2}{*}{$\begin{array}{l}\text { Nilai ADF } \\
\text { t-statistics }\end{array}$} & \multicolumn{3}{|c|}{ Nilai Kritis MacKinnom } & \multirow{2}{*}{ Prob. } & \multirow{2}{*}{ Keterangan } \\
\hline & & $1 \%$ & $5 \%$ & $10 \%$ & & \\
\hline IHSG & -0.795 & -3.610 & -2.939 & -2.608 & 0.809 & Tidak Stasioner \\
\hline KAP & -0.659 & -3.610 & -2.939 & -2.608 & 0.845 & Tidak Stasioner \\
\hline INF & -2.254 & -3.639 & -2.951 & -2.614 & 0.192 & Tidak Stasioner \\
\hline MNYK & -1.840 & -3.610 & -2.939 & -2.608 & 0.356 & Tidak Stasioner \\
\hline EMAS & -1.911 & -3.616 & -2.941 & -2.609 & 0.324 & Tidak Stasioner \\
\hline HSNG & -1.977 & -3.610 & -2.939 & -2.608 & 0.295 & Tidak Stasioner \\
\hline
\end{tabular}

Tabel 5. Uji stasioner pada first difference

\begin{tabular}{lcccccc}
\hline \multirow{2}{*}{ Variabel } & Nilai ADF & \multicolumn{3}{c}{ Nilai Kritis MacKinnom } & \multirow{2}{*}{ Prob. } & \multirow{2}{*}{ Keterangan } \\
\cline { 2 - 5 } & t-statistics & $1 \%$ & $5 \%$ & $10 \%$ & & \\
\hline IHSG & -4.401 & -3.616 & -2.941 & -2.609 & $0.0012^{* *}$ & Stasioner \\
KAP & -4.580 & -3.616 & -2.941 & -2.609 & $0.0007^{* *}$ & Stasioner \\
INF & -2.926 & -2.635 & -1.951 & -1.611 & $0.0047^{* *}$ & Stasioner \\
MNYK & -5.584 & -3.616 & -2.941 & -2.609 & $0.0000^{* *}$ & Stasioner \\
EMAS & -4.759 & -3.616 & -2.941 & -2.609 & $0.0004^{* *}$ & Stasioner \\
HSNG & -4.580 & -3.616 & -2.941 & -2.609 & $0.0007^{* *}$ & Stasioner \\
\hline
\end{tabular}

Keterangan: $* *$ ) data stasioner pada taraf $1 \% *^{*}$ ) data stasioner pada taraf $5 \%$

Tabel 6. Estimasi faktor-faktor yang mempengaruhi IHSG dalam jangka panjang

\begin{tabular}{lcccc}
\hline Variable & Coefficient & Std. Error & t-Statistic & Prob. \\
\hline KAPITALISASI & 0.709774 & 0.014776 & 48.03449 & $0.0000^{* * *}$ \\
INFLASI & -0.558484 & 0.240809 & -2.319199 & $0.0265^{* * *}$ \\
MINYAK & 0.057247 & 0.018880 & 3.032184 & $0.0046^{* * *}$ \\
EMAS & 0.050732 & 0.024955 & 2.032969 & $0.0499^{* * *}$ \\
HSNG & 0.233582 & 0.058021 & 4.025838 & $0.0003^{* * *}$ \\
C & -20.08028 & 0.359495 & -55.85699 & $0.0000^{* * *}$ \\
\hline R-squared & 0.996778 & \multicolumn{2}{c}{ Prob(F-statistic) } & 0.000000
\end{tabular}

Keterangan: $\left.{ }^{* * *}\right)$ signifikan pada taraf $\left.1 \% ;{ }^{* *}\right)$ signifikan pada taraf $\left.5 \% ;{ }^{*}\right)$ signifikan pada taraf $10 \%$.

R-Squared atau koefisien determinasi (R2) sebesar 0,996778, menunjukan bahwa seluruh variabel bebas dalam model dapat menjelaskan dengan baik variasi variabel terikat sebesar $99,68 \%$, sedangkan sisanya sebesar $0,32 \%$ dijelaskan oleh variabel lain diluar model. Hubungan pengaruh tersebut signifikan pada taraf $1 \%$. Hal ini terlihat dari nilai probabilitas F-statistik $0,000000<0,01$. Pengujian parsial pengaruh variabel independen terhadap variabel dependen, sebagai berikut:

Pengaruh kapitalisasi pasar saham

Pengaruh kapitalisasi pasar saham terhadap IHSG memiliki koefisien regresi sebesar 0,709774 dengan arah yang positif signifikan pada taraf $1 \%$. Terlihat nilai probabilitasnya sebesar 0.0000 lebih kecil dari 0,01 maka penelitian ini menolak hipotesis $\mathrm{H} 0: \beta 0=0$, dan menerima hipotesis $\mathrm{Ha}$ : $\beta \mathrm{i}>0$. Artinya, variabel independen kapitalisasi pasar saham memiliki pengaruh positif dan signifikan terhadap IHSG. Artinya, jangka panjang setiap peningkatan kapitalisasi pasar saham sebesar $1 \%$ akan meningkatkan IHSG sebesar $0,7 \%$ dan variabel lain dianggap tetap. Hasil penelitian ini sejalan dengan penelitian Prasetya (2000), Faried (2008) dan Subeniotis et al. (2011). Menurut Prasetya, nilai kapitalisasi berpengaruh positif terhadap return saham menunjukan periode bullish dan juga sebaliknya. Faried dan Subeniotis, menyatakan bahwa nilai kapitalisasi memiliki pengaruh yang signifikan terhadap indeks saham dengan arah positif. 
Pengaruh Inflasi

Pergerakan inflasi berpengaruh terhadap IHSG memiliki koefisien regresi sebesar 0,558484 dengan arah yang negatif signifikan pada taraf $1 \%$. Terlihat dari nilai probabilitas pengaruh tersebut sebesar 0,0265 lebih kecil daripada 0,05. Penelitian ini menolak hipotesis $\mathrm{H} 0: \beta 0=0$ dan terima hipotesis $\mathrm{Ha}: \beta \mathrm{i}<$ 0 . Artinya, dalam jangka panjang setiap peningkatan inflasi sebesar $1 \%$ maka akan menurunkan indeks harga saham gabungan sebesar $0,56 \%$ variabel lain dianggap tetap. Hasil penelitian ini sejalan dengan pendapat Hooker (2004) yang menyatakan bahwa tingkat inflasi memengaruhi secara signifikan terhadap harga saham. Peningkatan inflasi secara relatif merupakan sinyal negatif bagi pemodal di pasar modal. Sunariyah (2006), menyatakan hal yang sama bahwa inflasi memiliki hubungan negatif dengan pasar equitas.

\section{Pengaruh harga minyak dunia}

Harga minyak dunia berpengaruh terhadap IHSG sebesar 0,057247 dengan arah yang positif dan signifikan pada taraf $1 \%$. Terlihat dari nilai probabilitas sebesar 0,0046 lebih kecil dari 0,01. Penelitian ini menolak hipotesis $\mathrm{H} 0: \beta 0=0$, dan menerima hipotesis Ha: $\beta \mathrm{i}>0$. Artinya, setiap peningkatan harga minyak dunia sebesar $1 \%$, akan meningkatkan IHSG sebesar $0.057 \%$ dan variabel lain dianggap tetap. Hasil uji multikolinieritas variabel independen yang digunakan diperoleh nilai VIF < 10. Artinya, tidak terdapat multikolinieritas antara variabel bebas. Hasil penelitian ini sejalan dengan hasil penelitaian yang dilakukan oleh Hayo dan Kutan (2004) yang menyatakan harga minyak dunia berpengaruh positif terhadap pasar modal Rusia. Kilian dan Park (2007), dalam penelitiannya menyatakan bahawa harga minyak akan berdampak positif bagi pasar modal, apabila peningkatan harga minyak dunia disebabkan oleh peningkatan perekonomian global. Begitu juga dengan Witjaksono (2010) dan Handiani (2014), yang menyatakan hal yang sama bahwa harga minyak dunia mempunyai pengaruh yang positif terhadap harga saham.

\section{Pengaruh harga emas dunia}

Pergerakan harga emas dunia berpengaruh positif terhadap IHSG sebesar 0,050732 dengan arah yang positif dan signifikan pada taraf 5\%. Terlihat pada nilai probabilitas pengaruh tersebut sebesar 0,0499 lebih kecil dari 0,05 . Penelitian ini menolak hipotesis $\mathrm{H} 0: \beta 0$
$=0$, dan menerima hipotesis $\mathrm{Ha}: \beta \mathrm{i}>0$. Artinya, pada jangka panjang setiap peningkatan harga emas dunia sebesar $1 \%$ akan meningkatkan IHSG sebesar $0.051 \%$ variabel lain dianggap tetap. Hasil penelitian ini sejalan dengan hasil penelitian Twite (2002), Handiani (2014) dan Nisha (2015). Twite menyatakan harga emas berpengaruh positif terhadap pasar modal Australia. Sedangkan Handiani menyatakan harga emas dunia berpengaruh positif terhadap IHSG di BEI. Nisha, menyatakan bahwa harga emas berpengaruh positif terhadap bursa saham India. Berbeda dengan Smith (2001) yang menyatakan harga emas dunia berpengaruh negatif terhadap indeks harga saham Amerika Serikat.

\section{Pergerakan Indeks Hang Seng}

Pergerakan Indeks Hang Seng berpengaruh positif terhadap Indeks Harga Saham gabungan dengan koefisien regresi sebesar 0,233582 dengan arah positif dan signifikan pada taraf $1 \%$. Terlihat pada nilai probabilitas sebesar 0,0003 lebih kecil dari 0,01 . Penelitian ini menolak hipotesis H0 : $\beta 0=0$, dan menerima hipotesis $\mathrm{Ha}: \beta \mathrm{i}>0$. Artinya, pada jangka panjang setiap peningkatan Indeks Hang Seng sebesar $1 \%$ maka akan meningkatkan IHSG sebesar $0,23 \%$ dan faktor-faktor lain dianggap tetap. Hasil penelitian ini sejalan dengan hasil penelitian yang dilakukan Frensidy (2008), Wardana dan Manurung (2014). Frensdy menyatakan bahwa Indeks Hang Seng berpengaruh positif terhadap IHSG. Wardana dan Manurung, dalam penelitiannya menyatakan bahwa Indeks Hang Seng mempunyai hubungan yang searah dengan IHSG. Berbeda dengan penelitian Hartanto (2013) yang menyatakan Indeks Hang Seng tidak berpengaruh terhadap IHSG di BEI.

\section{Estimasi Faktor-faktor yang Memengaruhi IHSG dalam Jangka Pendek}

Hasil estimasi faktor faktor yang memengaruhi IHSG dalam jangka pendek dari model ECM yang menganalisis pengaruh kapitalisasi pasar saham dan variabel makroekonomi, dapat dilihat pada Tabel 7 . Syarat model ECM yang baik yaitu nilai coefficient ECT(-1) berada diantara -1 sampai 0, dan signifikan (prob. $<0.05$ ). Syarat model ECM telah terpenuhi karena nilai koefisien Error Correction Term ECT(-1) yang dihasilkan sebesar-0,207329 dan Prob (F-statistik) 0,000000 lebih kecil dari 0,05 menunjukkan bahwa disequlibrium periode sebelumnya terkoreksi pada periode sekarang sebesar $20,73 \%$. Artinya, jika terjadi 
gangguan (shock) proses penyesuaian (Adjusment Mechanism Prosses) pada keseimbangan jangka panjang berlangsung selama $1 / 0,207329=5$ triwulan.

\section{R-Squared (R2) sebesar 0,994383 menunjukan} bahwa seluruh variabel bebas dapat menjelaskan dengan baik variasi variabel terikat sebesar $99,44 \%$ sedangkan sisanya sebesar $0,56 \%$ dijelaskan oleh variabel lain diluar model. Secara simultan seluruh variabel independen berpengaruh dan signifikan pada taraf 1\%. Nilai probabilitas F-statistik 0,000000 lebih kecil daripada 0.01 . Faktor yang memengaruhi IHSG adalah variabel kapitalisasi pasar saham, inflasi, harga minyak dunia dan Indeks Hang Seng. Sedangkan harga emas dunia tidak berpengaruh. Penjelasan parsial dari variabel yang berpengaruh adalah sebagai berikut :

Pengaruh kapitalisasi pasar saham

Pengaruh kapitalisasi pasar saham terhadap IHSG memiliki koefisien regresi sebesar 0,986176 dengan arah yang positif dan signifikan pada taraf $1 \%$. Terlihat dari nilai probabilitas sebesar 0,0000 lebih kecil daripada 0,01. Penelitian ini menolak hipotesis H0 : $\beta 0=0$, dan menerima hipotesis $\mathrm{Ha}: \beta \mathrm{i}>0$. Artinya, dalam jangka pendek setiap peningkatan kapitalisasi pasar saham sebesar 1\% akan meningkatkan IHSG sebesar $0,99 \%$. Hasil penelitian ini sejalan dengan hasil penelitian Prasetya (2000), Faried (2008) dan Subeniotis et al. (2011). Menurut Praserya, kapitalisasi berpengaruh positif terhadap return saham pada periode bullish begitu sebaliknya. Penelitian Faried dan Subeniotis, menyatakan bahwa nilai kapitalisasi memiliki pengaruh positif terhadap indeks saham.

Pengaruh inflasi

Pergerakan inflasi berpengaruh terhadap IHSG memiliki koefisien regresi sebesar $-0,374005$ dengan arah yang negatif. Artinya, jangka pendek setiap peningkatan inflasi sebesar $1 \%$ maka akan menurunkan IHSG sebesar $0,37 \%$. Pengaruh tersebut signifikan pada taraf $1 \%$, terlihat nilai probabilitasnya sebesar 0,0100 sama dengan 0,01 , kesimpulan hipotesisnya tolak hipotesis $\mathrm{H} 0: \beta 0=0$ dan terima hipotesis $\mathrm{Ha}: \beta \mathrm{i}<0$. Artinya, variabel inflasi berpengaruh negatif dan signifikan terhadap IHSG. Hasil penelitian ini sejalan dengan penelitian yang dilakukan Hooker (2004), Sunariyah (2006) dan Prasetyanto (2016). Hooker menyatakan bahwa tingkat inflasi memengaruhi secara signifikan terhadap harga saham. Sunariyah menyatakan hal yang sama bahwa inflasi memiliki hubungan dengan pasar equitas. Prasetyanto juga menyatakan bahwa inflasi berpengaruh negatif dan signifikan terhadap IHSG.

Pengaruh harga minyak dunia

Harga minyak dunia berpengaruh terhadap IHSG sebesar -0,020066 dengan arah yang negatif, artinya setiap peningkatan harga minyak dunia sebesar $1 \%$ maka akan menurunkan IHSG sebesar $0,02 \%$. Pengaruh tersebut signifikan pada taraf $10 \%$. Terlihat dari nilai probabilitasnya sebesar 0,0976 lebih kecil daripada 0,1 maka kesimpulan hipotesisnya adalah tolak hipotesis $\mathrm{H} 0: \beta 0=0$ dan terima hipotesis $\mathrm{Ha}: \beta \mathrm{i}<0$. Artinya, variabel inflasi mempunyai pengaruh negatif dan signifikan terhadap IHSG. Hasil penelitaian sejalan dengan penelitian yang dilakukan oleh Kilian dan Park (2007), pada kesimpulan pertamanya menyatakan bahwa kenaikan harga minyak dunia berpengaruh negatif terhadap harga saham. Pengaruh negatif tersebut disebabkan oleh meningkatnya permintaan minyak dunia akibat ketidakpastian persediaan minyak dimasa depan. Penelitian ini berbeda dengan penelitian Hayo dan Kutan (2004), Valadkhani et al. (2006), McSweeny dan Worthington (2008), Witjaksono (2010) Handiani (2014) yang menyatakan harga minyak dunia berpengaruh positif terhadap indeks harga saham.

Tabel 7. Estimasi faktor-faktor yang mempengaruhi IHSG dalam jangka pendek

\begin{tabular}{lcccc}
\hline Variable & Coefficient & Std. Error & t-Statistic & Prob. \\
\hline D(KAPITALISASI) & 0,986176 & 0,026860 & 36,71544 & $0,0000^{* * *}$ \\
D(INFLASI) & $-0,374005$ & 0,136666 & $-2,736645$ & $0,0100^{* * *}$ \\
D(MINYAK) & $-0,020066$ & 0,011758 & $-1,706528$ & $0,0976^{* * *}$ \\
D(EMAS) & $-0,050312$ & 0,031058 & $-1,619973$ & $0,1151^{* * *}$ \\
D(HSNG) & 0,081337 & 0,027823 & 2,923369 & $0,0063^{* * *}$ \\
ECT2(-1) & $-0,207329$ & 0,096688 & $-2,144304$ & $0,0397^{* * *}$ \\
C & $-0,010580$ & 0,001775 & $-5,961197$ & $0,0000^{* * *}$ \\
\hline R-squared & 0,994383 & \multicolumn{2}{c}{ Prob(F-statistic) } & 0,000000 \\
\hline
\end{tabular}

Keterangan: $* * *)$ signifikan pada taraf $1 \% ; * *)$ signifikan pada taraf $5 \% ; *$ ) signifikan pada taraf $10 \%$. 
Pengaruh Indeks Hang Seng

Pergerakan Indeks Hang Seng memiliki pengaruh terhadap IHSG dengan koefisien regresi sebesar 0,081337 dengan arah yang positif, artinya dalam jangka pendek setiap peningkatan Indeks Hang Seng sebesar $1 \%$ maka akan meningkatkan IHSG sebesar $0,081 \%$. Pengaruh tersebut signifikan pada taraf $1 \%$. Terlihat dari nilai probabilitasnya sebesar 0,0063 lebih besar daripada 0,1 maka kesimpulan hipotesisnya menolak hipotesis $\mathrm{H} 0: \beta 0=0$, dan menerima hipotesis $\mathrm{Ha}: \beta \mathrm{i}$ $>0$. Artinya, dalam jangka pendek variabel independen Indeks Hang Seng memiliki pengaruh positif dan signifikan terhadap IHSG. Penelitian ini sejalan dengan hasil penelitian Frensidy (2006), menyatakan bahwa perubahan Indeks Hang Seng dalam jangka pendek berpengaruh positif dan signifikan terhadap IHSG. Wardana dan Manurung (2014) menyatakan pola pergerakan IHSG sama dengan pola pergerakan Indeks Hang Seng. Berbeda dengan penelitian dilakukan Hartanto (2013), yang menyatakan bahwa indek Hang Seng berpengaruh negatif terhadap IHSG.

\section{Strategi Meningkatkan Kapitalisasi Pasar Saham di Bursa Efek Indonesia}

Rumusanstrategimeningkatkankapitalisasi pasarsaham di BEI dilakukan untuk menjawab tujuan penelitian kedua. Terdapat lima tahap proses hirarki keputusan untuk menelusuri masalah melalui identifikasi sistem. Tahap pertama berupa fokus sebagai tujuan utama yang ingin dicapai. Tahap kedua, faktor yang merupakan indikator penting memengaruhi strategi. Tahap ketiga aktor yang memiliki peran penting dalam keberhasilan strategi. Tahapan ke-empat tujuan yang ingin dicapai dan diperkirakan dapat mendukung tercapainya tujuan utama. Tahap ke-lima, alternatif strategi yang dapat dijalankan untuk mencapai strategi utama. Hierarki analisis vertikal dari AHP pada Gambar 2.

Hasil analisis vertikal pada Gambar 2, pada level faktor yang menjadi prioritas adalah Kebijakan (Pasar modal dan moneter) dengan bobot sebesar 0,564. Pada level Aktor lebih prioritas pada Bursa Efek Indonesia dan Bank Indonesia dengan bobot sebesar 0,478. Pada level tujuan memiliki prioritas yaitu iklim investasi dan stabilitas ekonomi yang kondusif dengan bobot sebesar 0,417. Pada level alternatif strategi memiliki prioritas pada mendorong peningkatan investasi saham-saham berkapitalisasi besar dengan bobot sebesar 0,469.

\section{Implikasi Manajerial}

Pemerintah harus meningkatkan kapitalisasi pasar saham di BEI dengan prioritas strategi mendorong peningkatan investasi saham-saham berkapitalisasi besar. Selanjutnya, pemerintah selalu mengendalikan laju inflasi, mewaspadai gejolak harga minyak dunia. dan pergerakan Indeks Hang Seng. Bagi emiten, pasar modal hendaknya dijadikan sarana untuk mendapatkan dana pengembangan usaha, menerapkan good corporate governance untuk meningkatkan kinerja perusahaan dan daya saing industri, mewaspadai laju inflasi, harga minyak dunia. dan pergerakan Indeks Hang Seng yang menurun karena kan berdampak searah pada IHSG. Bagi investor, hendaknya meningkatkan investasinya di BEI. Selalu memperhatikan pergerakan saham yang bersifat historis. Mewaspadai gejolak makro ekonomi, seperti inflasi, perubahan harga minyak dunia dan indeks regional Hang Seng. Laju inflasi harus menjadi prioritas utama karena inflasi memiliki pengaruh negatif terhadap pergerakan harga saham. Begitu juga dengan kenaikan harga minyak dunia karena harga minyak dunia dalam jangka pendek berpengaruh negatif terhadap harga saham. Disamping itu investor juga harus memperhatikan indeks regional Hang Seng, karena indeks ini mempunyai hubungan searah dengan IHSG.

\section{KESIMPULAN DAN SARAN}

\section{Kesimpulan}

Hasil analisis menyimpulkan bahwa seluruh variabel independen secara umum dalam estimasi jangka panjang berpengaruh positif dan signifikan hanya inflasi berpengaruh negatif signifikan. Pada estimasi jangka pendek, variabel yang berpengaruh adalah kapitalisasi pasar saham, inflasi, harga minyak dunia dan Indek Hang Seng, sedangkan harga emas dunia tidak berpengaruh. Kapitalisasi pasar saham dan Indeks Hang Seng berpengaruh positif. Sedangkan inflasi dan harga minyak dunia berpengaruh negatif. Pada estimasi jangka pendek disequilibrium periode sebelumnya terkoreksi pada periode sekarang sebesar $20,73 \%$. Artinya, bila terjadi shok proses penyesuaian (Adjusment Mechanism Prosses) pada keseimbangan jangka panjang akan berlangsung selama lima triwulan atau selama 1,25 tahun. 
Kapitalisasi pasar berpengaruh positif dan dominan dibandingkan variabel makroekonomi, baik dalam jangka pendek maupun jangka panjang. Untuk itu diperlukan strategi peningkatan kapitalisasi pasar saham di BEI. Faktor yang menjadi prioritas strategi adalah kebijakan (pasar modal dan moneter). Aktor yang menjadi prioritas adalah BEI dan BI. Tujuan yang menjadi prioritas adalah terciptanya iklim investasi dan stabilitas ekonomi yang kondusif. Strategi alternatif yang menjadi prioritas yaitu mendorong peningkatan investasi saham berkapitalisasi besar.

\section{Saran}

Penelitian ini memiliki keterbatasan maka untuk meminimalisirketerbatasantersebut diajukan saranyaitu bahwa persamaan model ECM ini memiliki variabelvariabel diluar model yang mungkin berpengaruh pada pergerakan IHSG. Penelitian lanjutan diharapkan dapat membangun model variabel lain yang memberikan pengaruh terhadap IHSG di BEI. Misalnya memasukan variabel makro non-ekonomi.

\section{DAFTAR PUSTAKA}

Aditya, Sinaga BM, Maulana TBA. 2018. Pengaruh indeks bursa luarnegeri, indikator makroekonomi dan krisis ekonomi global terhadap Indeks Harga Saham Gabungan di Indonesia. Jurnal Aplikasi Manajemen dan Bisnis 4(2):284-295. https:// doi.org/10.17358/jabm.4.2.284.

Amran I. 2015. Gejolak IHSG : Ini penyebab pasar modal RI goyah versi bursa efek. http://market. bisnis.com. [2018 Agustus 11].

Astuti R, Lapian J, Paulina RV. 2016. Pengaruh faktor ekonomi terhadap Indeks Harga Saham Gabungan (IHSG) di Bursa Efek Indonesia (BEI) periode 2006-2015. Jurnal Berkala Ilmiah Efisiensi 16(2):399-406.

Bettman JL, Kelvin WS, Sault SJ. 2011. The economic significance of trading based on the size effect in Australia. Australian Journal of Management 36(1):59-73. https://doi. org $/ 10.1177 / 0312896210388860$.

Djumena E. 2017. Kenaikan indeks harga saham di Bursa Efek Indonesia tertinggi di dunia.https:// ekonomi.kompas.com. [ 11 Agustus 2018].

Faried RA. 2008. Analisis pengaruh faktor fundamental dan nilai kapitalisasi pasar terhadap return saham perusahaan manufaktur di BEI periode 2002 sampai 2006 [tesis]. Semarang: Universitas Diponegoro.

Firdaus M. 2012. Seri Metode Kuantitatif : Aplikasi Ekonometrika untuk Data Panel dan Time Series. Bogor: IPB Press.

Frensidy B. 2006. Analisis pengaruh aksi beli-jual, kurs dan Indeks Harga Saham Gabungan di BEI dengan model GARCH. Jurnal Riset Bisnis dan Manajemen 8(3):43-50.

Halim J. 2011. Analisis pengaruh pergerakan busrsa internasional terhadap pergerakan Bursa Indonesia. Journal of Applied Finance and Accounting 3(2):181-203.

Handiani S. 2014. Pengaruh harga emas dunia, harga minyak dunia dan nilai tukar dolar Amerika/ rupiah terhadap indeks harga saham gabungan pada periode 2008-2013. Journal of Graduate Unpar 1(1):85-93.

Hartanto A. 2013. Analisis hubungan antar negara G20 dan perwujudan Indeks Harga Saham Gabungan. FINESTA 1(2):16-27.

Hayo B, Kutan AM. 2004. The impact of news, oil prices and global market developments on Russian financial markets. in: International Conference 2004. The William Davidson Institute Michigan, February 2004. https://doi. org/10.2139/ssrn.517664.

Hooker, Mark A. 2004. Macroeconomic factors and emerging market equity return: a Bayesian model selection approach. Emerging Market Review 5(3):379-387. https://doi.org/10.1016/j. ememar.2004.09.001.

Kilian L, Park C. 2007. The impact of oil price shocks on the US stock market. International Economic Review 50(4):1267-1287. https://doi. org/10.1111/j.1468-2354.2009.00568.x.

Ma'arif MS, Tanjung H. 2003. Teknik-Teknik Kuantitatif untuk Manajemen. Jakarta: Grasindo.

Marimin, Magfiroh N. 2013. Aplikasi Teknik Pengambilan Keputusan dalam Manajemen Rantai Pasok. Bogor: IPB Press.

McSweeney, Evan J, Worthington, Andrew C. 2008. A comparative analysis of oil AS a risk faktor in Australia industry stock return 1980-2006. Journal of Emeral Studies in Economic and Finance 25(2):21-33. https://doi. org/10.1108/10867370810879447.

Mulyono. 2015. Analisa Korelasi return indeks - indeks saham terhadap indeks harga saham gabungan pada Bursa Efek Indonesia. Binus Business Review 6(2):330-339. https://doi.org/10.21512/ 
bbr.v6i2.982.

Nachrowi DN, Usman H. 2006. Pendekatan Populer dan Praktis, Ekonometrika Untuk Analisis Ekonomi dan Keuangan. Jakart: Penerbit Fakultas Ekonomi Universitas Indonesia.

Nisha N. 2015. Dampak variabel makro ekonomi terhadap pengembalian saham: Bukti dari Bombay Stock Exchange (BSE). Investasi dan Manajemen 4(5):67-79.

Odior ES, Nwaogwugwu IC. 2016. Efficiency of the Nigerian stock market with respect to pure contemporary monetary policy instruments: a dynamic weighted LS approach. Journal of Applied Finance and Banking 6(4):83-105.

Prasetya T. 2000. Analisa rasio keuangan dan nilai kapitalisasi pasar sebagai prediksi harga saham di BEJ pada periode bullish dan bearish. Prosiding Simposium Nasional Akuntansi III; 2000 Agustus 4; Jakarta, Indonesia. Jakarta: Fakultas Ekonomi Universitas Indonesia. hal. 652-659.

Prasetyanto KP. 2016. Pengaruh produk domestik bruto dan inflasi terhadap Indeks Harga Saham Gabungan di Bursa Efek Indonesia tahun 2002-2009. Jurnal Riset Akuntansi dan Bisnis Airlangga (Jraba) 1(1):2548-1401. https://doi. org/10.31093/jraba.v1i1.9.

Rahman M, Kuhan K, Kavida V. 2017. Impact of selected macroeconomic indicators on S\&P, BSE, SME, IPO INDEX. Indian Journal of Commerce \& Management Studies 8(1):28-32. https://doi.org/10.18843/ijcms/v8i1/04.

Smith G. 2001. The price of gold and stock price indices for the united states. Adrienne Robert FT
Personal Finance 27(14):67-80.

Subeniotis ND. Papadopoulos LD. Tampakoudis AL. Tampakoudi A. 2011. How inflation, market capitalization, industrial production and ecomic sentiment indicator affect the UE-12 stock markets. European Research Studies 14(1):103117.

Sulistya RAW. 2008. Hubungan antara variabel makroekonomi dan beberapa indeks dunia terhadap Indeks Harga Saham Gabungan (IHSG) dengan pendekatan analisis kointegrasi [tesis]. Jakarta: Universitas Indonesia.

Sunariyah. 2006. Pengantar Pengetahuan Pasar Modal. Ed ke-5. Yogyakarta: UPP STIM YPKP.

Twite G. 2002. Gold prices, exchange rates, gold stocks and the gold premium. Journal Australian of Management 27(2):123-140. https://doi. org/10.1177/031289620202700202.

Valadkhani A, Chancharat S, Havie C. 2006. The interplay between the Thai and several other interrnasional stock market. Economic Working Papers No. 154.

Wardana DG, Manurung HA. 2014. Pembentukan portofolio saham optimum dengan model Elton Gruber dan variabel makro yang memengaruhinya. Pasar Modal dan Perbankan 2(3):26-51.

Witjaksono AA. 2010. Analisis pengaruh tingkat suku bunga SBI, harga minyak dunia, harga emas dunia, kurs rupiah, indeks Nikkei 225, dan indeks Dow Jones terhadap IHSG [tesis]. Semarang: Universitas Diponegoro. 